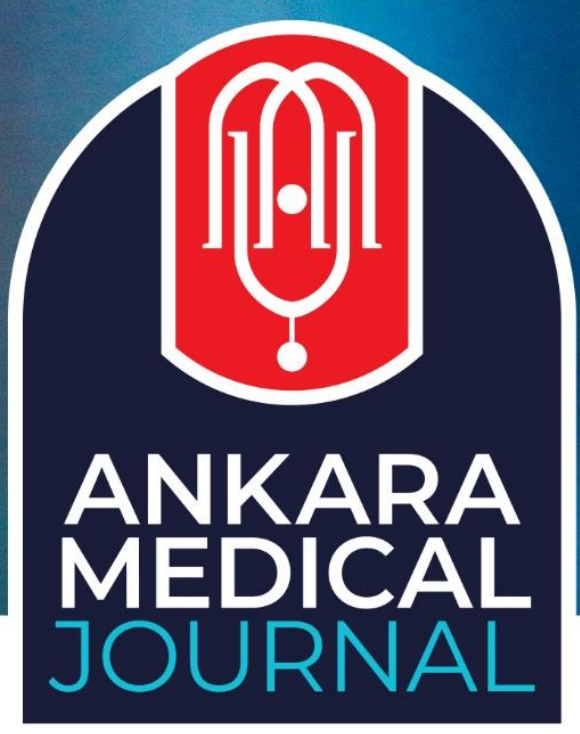

Research Article

Ankara Med J, 2020;(3):541-552 // 10 10.5505/amj.2020.79847

\title{
THE EFFECT OF MUSIC ON PAIN AND ANXIETY IN EPISIOTOMY
}

MÜZİĞİN EPIZYOTOMİDEKI AĞRI VE ANKSIYYTEYE ETKISİ

(D) Ali Doğukan Anğın', (D) Muhammet Ali Oruç², (D) Abdulmecit Öktem³, (D) Türkan Gürsu', (D) Yasemin Alan5, (D) Onder Sakin1,

(D) Mustafa Gökkaya1, (D) İsmet Gün6, (D) Emine Eda Akalın', (D) Kazibe Koyuncu' ${ }^{1}$, (D) Ramazan Denizli7

1Sağlık Bilimleri Üniversitesi, Dr Lütfi Kırdar Kartal Eğitim Araştırma Hastanesi, Kadın Hastalıkları ve Doğum Bölümü

${ }^{2}$ Ahi Evran Üniversitesi Aile Hekimliği AD.

${ }^{3}$ Sağlık Bilimleri Üniversitesi, Tepecik Eğitim Araştırma Hastanesi Kadın Hastalıkları ve Doğum Bölümü ${ }^{4}$ Sağlık Bilimleri Üniversitesi, Zeynep Kamil Kadın Sağlığı ve Çocuk Hastanesi, Kadın Hastalıkları ve Doğum Bölümü

5İzmir Büyükșehir Belediyesi Eșrefpaşa Hastanesi, Kadın Hastalıkları ve Doğum Bölümü

6Yakın Doğu Üniversitesi Tıp Fakültesi, Kadın Hastalıkları ve Doğum Bölümü

${ }^{7}$ Artvin Arhavi Devlet Hastanesi, Kadın Hastalıkları ve Doğum Bölümü

Yazışma Adresi / Correspondence:

Yasemin Alan (e-mail: jasminalann@hotmail.com)

Geliş Tarihi (Submitted): 11.02.2020 // Kabul Tarihi (Accepted): 08.09.2020

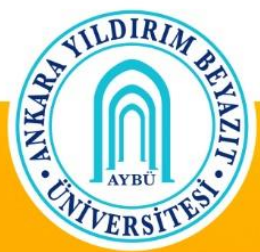

Ankara YIldırım Beyazıt University Faculty of Medicine

Department of Family Medicine 


\section{Öz}

Amaç: Doğum eylemi, ciddi ağrıya yol açtığı bilinen, bu sebeple belirgin stres, anksiyete ve hatta depresyona yol açabilen bir durumdur. Bu çalışmamızda doğumun ikinci evresinin aktif fazı sonu ile başlayan ve epizyotomi onarımının tamamlanmasına kadar geçen sürede, müzik dinletisinin, epizyotomi onarımı sırasındaki ağrı ile anksiyete, stres ve depresyon düzeylerine olan etkisini araştırdık.

Materyal ve Metot: Çalışmaya 2017-2019 yılları arasında vajinal doğum yapması planlanan 90 gebe hasta dahil edildi. Doğum eyleminin 1. evresinin aktif fazının sonundan, restriktif mediolateral epizyotomi onarımının tamamlanmasına kadar müzik çalındı. Hastalar dinlenen müzik türüne göre rastgele üç gruba ayrıldı: Klasik müzik $(n=30)$, Türk pop müziği $(n=30)$ ve kontrol grubu $(n=30)$. Kontrol grubuna yalnızca gürültüyü azaltan bir kulaklık verildi. Stres, anksiyete ve depresyonu değerlendirmek için DASS-42 ve ağrıyı değerlendirmek için Görsel Analog Ağrı Ölçeği (VAS) kullanılarak üç grubun sonuçları karşılaştırıldı.

Bulgular: Yapılan değerlendirmeler sonucunda gruplar arasında anksiyete ve depresyon skorlarında belirgin bir farklılık elde edilemese de; stres skorunun ikinci grupta anlamlı olarak düștüğü görüldü. Fakat bu düșüșün ağırlıklı olarak çalışan ve çalışmayan hastalar arasındaki farktan kaynaklandığı görüldü. Ağrı skorları arasında da anlamlı fark elde edilemedi.

Sonuç: Stres skorlarındaki iyileşme, hastaların anadillerinde çalınan bir müziği dinlediklerinde daha dikkat çekici şekilde belirgindir. Müzik dinletisinin, epizyotomiye bağlı ortaya çıkan ağrının dindirilmesinde ise beklendiği kadar etkin olmadı̆̆ı görülmüştür.

Anahtar Kelimeler: Doğum, epizyotomi, müzik, stres, anksiyete, depresyon, ağrı

\footnotetext{
Abstract

Objectives: Labor is known to cause severe pain; therefore, it can lead to significant stress, anxiety, and even depression. We investigated the effect of listening to music from the end of the active stage of labor until the completion of episiotomy repair on pain, anxiety, stress, and depression levels.

Materials and Methods: The study includes 90 pregnant patients that were planned to have vaginal delivery between 2017 and 2019. We played music starting from the end of the active phase of the 1sth stage of labor until the completion of the repair of restrictive mediolateral episiotomy. The subjects were randomly divided into three groups: classical music $(n=30)$, Turkish pop music $(n=30)$, and control group $(n=30)$. The control group was only provided with a headset that would reduce noise. We used DASS-42 to evaluate stress, anxiety and depression, and the Visual Analogue Scale for Pain (VAS) to evaluate pain. We compared the results of the three groups.

Results: The anxiety and depression scores of the three groups were not significantly different; however, stress findings were significantly lower in the Turkish pop music group. We observed that this result was majorly associated with the working status of the mother. The pain results of the three groups were not significantly different.

Conclusion: Music should be noted that this effect is especially prominent when the music is in the patient's native tongue. Also, we conclude that playing music is not as effective as expected in relieving pain caused by episiotomy.

Keywords: Labor, episiotomy, music, stress, anxiety, depression, pain
} 


\section{Introduction}

The severe pain of labor and uncertainty about what the patient will experience in the next stage can cause increased anxiety, stress and depression in expectant mothers. ${ }^{1,2}$ It is known that the stress state caused by the concern and anxiety felt by the mother is effective on the affection and stress level of the newborn baby. Various sounds and noises in the place where the labor takes place is also thought to be effective on this situation. There is a widespread opinion that feeling comfortable and peaceful of pregnant women directly affects the course of labor.3,4,5 Many authors agree on the fact that being stable and positive of the mother's emotional state during delivery has an effect on facilitating delivery and even decreasing complication rates. ${ }^{6,7}$

Music is universally accepted as a tool that reduces stress level and anxiety. It has been proven with many studies that sleep patterns can be provided by listening to music, effectiveness and motivation can be increased in the study, and moreover, psychologically significant relief can be obtained. ${ }^{8,9}$ It is widely accepted worldwide that meditation accompanied by music has a relaxing effect. ${ }^{10,11}$ In addition to using music as supportive therapy in the treatment of many diseases, music is also used as a relaxing factor for patients and facilitating factor in many interventional procedures. In addition to all of this, even though there are many discussions on this, there are also many studies showing that making the baby in the womb listen to different music genres has a positive effect on the development of the intelligence of the baby. ${ }^{11,12}$

Very limited number of studies conducted in this area suggested that playing music to women could restore the sleep pattern that was disturbed during pregnancy and provide some relief in labor. ${ }^{13,14}$ In this study, we investigated the effect of listening to music on pain and anxiety, stress and depression levels during episiotomy repair, in the ti me starting with the active phase of the second stage of labor, until the completion of episiotomy repair.

\section{Materials and Methods}

This study was planned as a prospective, randomized, controlled study. A total of 130 pregnant women who were admitted to the Istanbul Dr. Lütfi Kirdar Training and Research Hospital Gynecology and Obstetrics for labor between January 2017 and November 2019 accepted to participate and 90 patients fullfilled the criteria and were included to the study. Verbal and written informed consent was obtained from all patients. The study was granted ethical approval by the Kartal Dr. Lütfi Kırdar Training and Research Hospital Ethics Committee (Date 13.12.2017, Decision number:2017/514/119/3). Also our study was carried out in accordance with the Helsinki Declaration of Principles. From the demographic characteristics of the patients, maternal age, number of pregnancies, parity, birthweeks, birth weights of the babies, body mass indexes of the pregnant women, whether they smoke or not, their educational status, whether they worked in any job were determined. The 
patients were randomized into three groups according to the genres of music played from the active phase of the 2nd stage of labor to the end of right restrictive mediolateral episiotomy repair. The reason for choosing these stages of labor was that the back pain and discomfort which are results of increasing frequency and intensity of uterine contractions, become more intense at these stages. Even though local anesthesia is applied while the episiotomy line is being sewn in current practice, some pregnant women still experience pain. The reason why we chose different genres and sources of music such as Turkish Pop music and world music was to investigate the culture-dependent effect of music on labor. The music playing action was applied via headsets to each patient by the ones who were carrying out the study, with the sound level being 60-70 dB. For each of 2 separate music CDs 10 copies, prepared for making the patients listen to music, containing classical music or Turkish pop music, with a total playing time of 90 minutes, were prepared. In Group $1(\mathrm{n}=30)$ music was played as classical music (Mozart-Concerto for flute and harp, JS Bach -Prelude No.1, Chopin -Nocturne No.2 Op.9, Beethoven-Moonlight Sonata, Debussy-Rêverie, which were performed with piano, flute, violin, harp, and guitar). In Group 2 ( $n=30)$ music was played as Turkish pop music (the first 30 songs most frequently played in 3 different national radio channels broadcasting Turkish pop music at the time of the study). In Group 3 (n $=30$ ), selected as the control group, the patients used the headsets that only reduced hearing the voices in the delivery room, and the music was not played. The reason for choosing limited episiotomy for our patients was that limited episiotomy was reported to be associated with a lower risk of perineal trauma, less need for suturing and less complications compared to routine episiotomy. ${ }^{15}$ After injection of two vials of jetokain in the episiotomy line of all patients, a restrictive (as much, minimum) mediolateral episiotomy was performed with a blunt episiotomy scissors. After the delivery and the separation of the placenta, the cut line was sutured by one of the two authors with at least 5 years of experience in obstetrics by one-fold, continuous $2 / 0$ vicryl by locking. The skin was individually sutured with $2 / 0$ vicryl.

The Visual Analog Scale (VAS) was used to assess the stress levels of the women in labor. VAS consisted of a 10 cm line drawn horizontally. The scale, which was designed as "absolutely calm" at the left end and "extremely distressing" at the other, was evaluated with a single score given by the observer. ${ }^{16}$ Depression Anxiety Stress Scale (DASS 42) is a 4-point Likert-type scale consisting of 42 items in total, 14 items each in the depression, anxiety and stress sub-dimensions. This scale, developed by Lovibond and validity and reliability in Turkish confirmed by Bilgel and Bayram, consists of 3 subscales. The sum of the individual scores is taken for each subscale for analysis and 0-9 points for depression, 0-7 points for anxiety and 0-14 points for stress are considered normal. As the individual subscale scores increases, the severity of depression, anxiety and stress increases. ${ }^{17}$ After the repair was completed, VAS scoring (visual analog scale, 0 no pain at all -10 maximum pain level) for pain in the episiotomy process and DASS 42 questionnaire for anxiety, stress, and depression levels were performed to patients by 2 different experts from the team who conducted the study (Figures 1 and 2 ). Episiotomy repair times were recorded in minutes. VAS scoring, DASS 42 questionnaire and episiotomy time were compared between 3 groups. 
The criteria for inclusion in the study were determined as to be aged between 23 and 40, being at the 37 th41th weeks of gestation, being of baby birth weight between 2500-4000gr, having a restrictive right mediolateral episiotomy, vertex arrivals, having a follow-up with vaginal delivery.

The exclusion criteria for the study are as follows: non-vertex arrivals, IUGR (intrauterine growth retardation), communication problem (hearing impairment, mental retardation in the mother), chronic pain problem, administration of extra analgesia or anesthesia such as epidural analgesia for delivery, intrauterine death, fetal malformations, having difficulties in understanding VAS scoring, delivery by cesarean section, formation of extra perineal lacerations other than episiotomy line due to shoulder stuck and no need for episiotomy.

\section{Statistical analysis}

SPSS 20 (IBM Corp, 2011, IBM SPSS Statistics for Windows, Version 20.0. Armonk, NY: IBM Corp.) statistical package program was used to evaluate the data. Variables mean \pm standard deviation and Median (MaximumMinimum) percentage and frequency values were used. Normality test was evaluated with KolmogorovSmirnov and Shapiro Wilk tests. For group comparison of three or more One-way Analysis of Variance and Tukey HSD test, which is one of the multiple comparison tests; when prerequisites were not met, Kruskal Wallis and Bonferroni-Dunn test, which is one of the multiple comparison tests, were used. Group categorical comparisons were performed with chi-square test. For the statistical significance level of the tests, $p<0.05$ value was accepted.

\section{Results}

The mean gravida, parity, gestational week, baby birth weight, maternal body mass index (BMI) and episiotomy repair times belonging to the 3 groups created are given in Table 1. When the groups are compared in terms of BMI, it was found that the index of 7 patients (23.3\%) in group 1,14 patients (46.7\%) in group 2 and 18 patients $(60.0 \%)$ in group 3 was above 30 and the difference was significant $(p=0.016)$. While there is a significant difference in baby birth weights between groups; there was no difference in terms of gravida, parity, gestational week and episiotomy repair times. It was observed that, of the patients 27 (90\%) in the group 1, 28 (93.3\%) in group 2 and 26 (86.7\%) in group 3 were smokers and there was no significant difference between the groups in terms of smoking rates. Similarly, no statistically significant difference was detected between the groups in terms of education level. It was observed that the highest non-working rate was in group 1, the lowest nonworking rate was in group 3, and there was a significant difference between the groups in terms of working rates. It was determined that the deliveries of the patients in group 1 and 3 took place mostly during out of normal working hours, the deliveries of the patients in the group 2 took place frequently within working hours, and that this difference in group 2 was significant. There was no significant difference between the groups in 
terms of parity. When the normality tests were applied to the parameters in question, only BMI complied with normality test.

When DASS scoring is performed between the groups, it was observed that stress scores were the lowest in group 2 (16 patients in Group 1-53.3\% score: 0, 25 patients in Group 2 -83.3 \% score: 0, 8 patients in Group 3 -26.7 \% score: 0 ) and the difference was statistically significant. (Table 2).

There was no statistically significant difference between group 1, group 2 and group 3 in terms of VAS scores $(p=0.085)$.

Table 1. Comparison of demographic data between groups

\begin{tabular}{|c|c|c|c|c|c|}
\hline & & GROUP 1 & GROUP 2 & GROUP 3 & $p$ \\
\hline \multicolumn{2}{|l|}{ gravida } & $2.63 \pm 1.69$ & $2.13 \pm 1.14$ & $2.6 \pm 1.38$ & 0.339 \\
\hline \multicolumn{2}{|l|}{ parity } & $1.37 \pm 1.43$ & $1.03 \pm 1.03$ & $1.33 \pm 1.16$ & 0.499 \\
\hline \multicolumn{2}{|c|}{ gestational week } & $39.2 \pm 1.32$ & $39.03 \pm 1.32$ & $38.33 \pm 1.29$ & 0.542 \\
\hline \multicolumn{2}{|c|}{ baby birth weight (grams) } & $3321.33 \pm 640.74$ & $3199.17 \pm 376.81$ & $3391.33 \pm 673.64$ & 0.027 \\
\hline \multicolumn{2}{|c|}{$\begin{array}{l}\text { episiotomy repair time } \\
\text { (minute) }\end{array}$} & $16.47 \pm 7.06$ & $17.47 \pm 7.92$ & $14.27 \pm 6.05$ & 0.173 \\
\hline \multicolumn{2}{|l|}{ BMI $\left(\mathrm{kg} / \mathrm{m}^{2}\right)$} & $28.15 \pm 3.34$ & $29.26 \pm 4.2$ & $30.21 \pm 3.01$ & 0.08 \\
\hline \multirow{2}{*}{ smoking } & $(+)$ & $3(10)$ & $2(6.7)$ & $4(13.3)$ & \multirow[t]{2}{*}{0.690} \\
\hline & $(-)$ & $27(90)$ & $28(93.3)$ & $26(86.7)$ & \\
\hline \multirow{3}{*}{$\begin{array}{l}\text { education } \\
\text { status }\end{array}$} & \multirow{3}{*}{$\begin{array}{l}\text { sprimary } \\
\text { school } \\
\text { middle school } \\
\geq \text { high } \\
\text { school }\end{array}$} & $8(27)$ & $16(53.3)$ & $10(33.3)$ & \multirow{3}{*}{0.157} \\
\hline & & $14(46)$ & 5 (16.7) & $9(30)$ & \\
\hline & & $8(27)$ & $9(30)$ & $11(36.7)$ & \\
\hline \multirow{2}{*}{ work status } & \multirow{2}{*}{$\begin{array}{l}\text { working } \\
\text { unemployed }\end{array}$} & $1(3.4)$ & 5 (16.7) & $11(36.7)$ & \multirow[t]{2}{*}{0.04} \\
\hline & & $29(96.6)$ & $25(83.3)$ & $19(63.3)$ & \\
\hline \multirow{2}{*}{ delivery time } & \multirow{2}{*}{$\begin{array}{l}\text { shift } \\
\text { out of shift }\end{array}$} & $8(27)$ & $17(57$ & $8(27)$ & \multirow[t]{2}{*}{0.021} \\
\hline & & $22(73)$ & $13(43)$ & $22(73)$ & \\
\hline
\end{tabular}

Data are given as mean \pm Std. deviation or as $n(\%)$. 
Table 2. Comparison of DASS 42 values and VAS total score averages

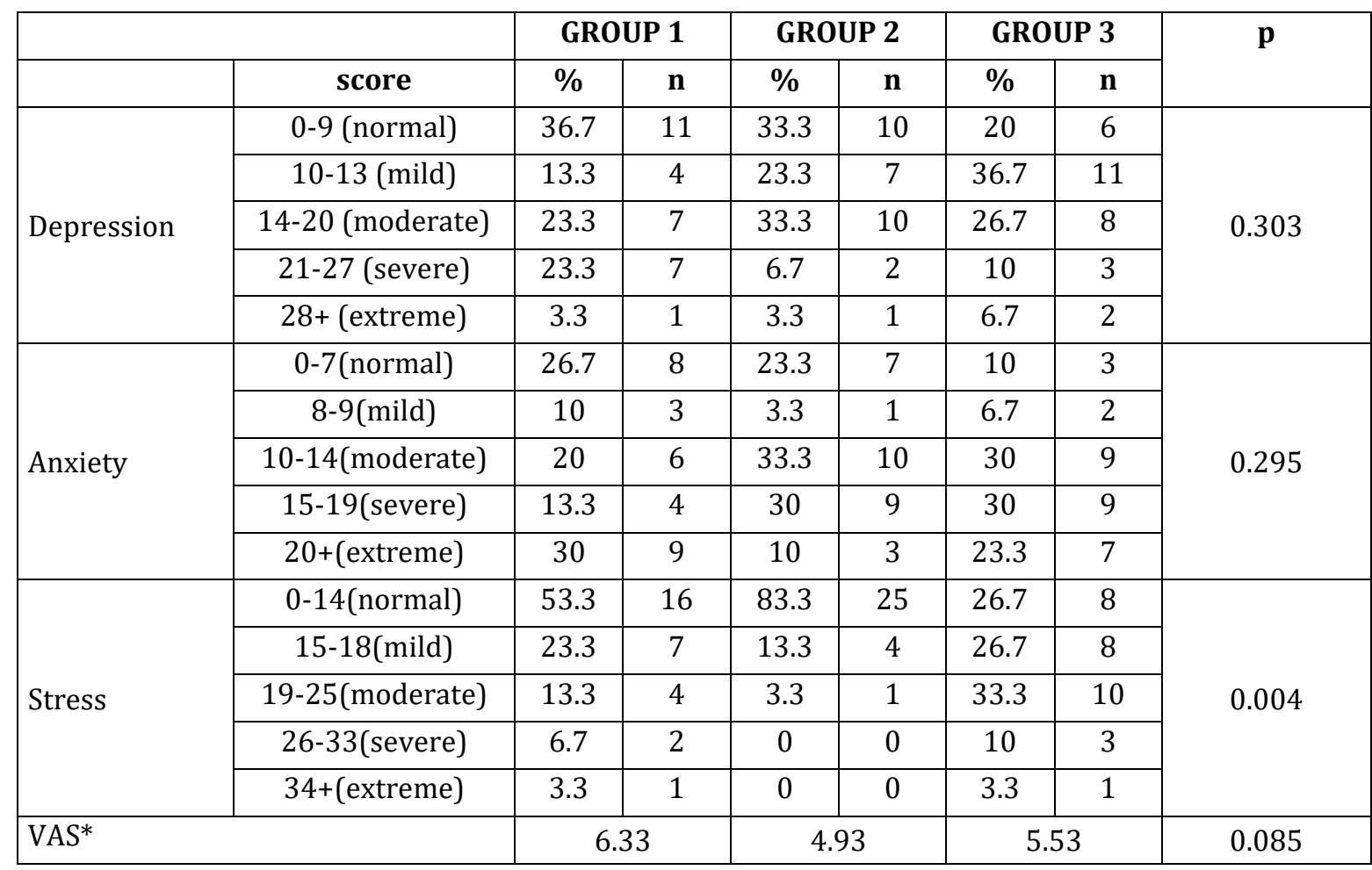

* Total VAS score mean value

\section{Discussion}

Labor is known as a serious source of pain for expectant mothers. Therefore, labor can often lead to stress, anxiety and even depression in mothers. For this reason, many methods have been tried to decrease the anxiety levels of mothers and to provide a more comfortable and problem-free delivery. Among these, various drugs, psychological inspiration methods and regulation of environmental conditions are the first ones that come to mind. ${ }^{18,19}$

Music is a method that is thought to have a relaxing and restful effect on human nature and consequently has been used in the treatment of many diseases throughout history. It is thought that making patients listen to music is effective in restoring sleep patterns that are impaired in pregnant women and even contributes to a more comfortable delivery. ${ }^{20}$ There are studies indicating that making patients listen to music facilitates not only normal delivery but also cesarean delivery. ${ }^{14}$

The disturbing situation caused by auditory stimuli and stress can be reduced by the relaxing effect of music. It has been suggested that there was a relationship between pain and positive activation of the auditory 
pathways. Activation of the auditory canal with appropriate music may play an important role in blocking the central distribution of painful stimuli.21

In our study, the effect of listening to music on pain and anxiety, stress and depression levels during episiotomy repair, in the time starting with the active phase of the second stage of labor, until the completion of episiotomy repair was investigated, and the fact that whether different music genres have different effects in this field was also examined.

There are a limited number of studies in the literature about the effects of music on different stages of labor. One of the most important of these is the study of Simavlı et al. on 156 primipara pregnant, who are expected to have vaginal delivery. In this study, the results of 77 patients who had listened to music and 79 patients who constituted the control group were compared over different parameters and as a result, it has been shown that listening music during delivery had a positive effect on labor pain, maternal-fetal parameters, analgesic need and anxiety. ${ }^{20}$ In our own study, in which the effect of different music genres on anxiety arising from labor is evaluated, no clear effect on anxiety was detected and it was observed that this situation did not change with music genres played.

Every patient has a different sensitivity to music. Every mother wants her pain to cease completely during delivery. The net effect of music on this issue is still controversial. The musical education received by the patient and his/her attitude towards music may be important in this subject, as well as the education and behavioral status of the patient. ${ }^{22,23}$

It has been reported that different music genres provided a decrease in the pain and anxiety levels of pregnant women in labor. Labor pain begins with mild pain starting from the latent phase, and in the active phase, pain in the uterine area continues to increase. In the second stage, the intensity and region of the pain changes and turns into severe uterine and perineal pain. ${ }^{24}$ Especially in the first phase, mild and moderate pain may turn into severe pain with the effect of fear and anxiety. ${ }^{25,26}$ Therefore, pregnant women should be helped to cope with pain during labor. It was suggested that light music played to pregnant women in the first stage had a calming effect on women. ${ }^{21}$ Similarly, studies have also shown that music played in the latent phase reduces the pain and anxiety levels of pregnant women. ${ }^{27}$ In our study, unlike the literature, we found that music did not change the pain and anxiety levels of pregnant women in labor. This may be the result of the fact that the music was only delivered during the active phase of birth.

In their study, Gonzalez et al. stated that expectant mothers with term pregnancy listen to music in the prenatal period and that music has a facilitating effect on birth. In the same study, it has been reported that a decrease in anxiety was achieved during NST (non-stress test). ${ }^{28}$ Although the effect of music on anxiety during NST follow-up was not evaluated in our study, no significant improvement was provided in the anxiety level until 
the repair of the episiotomy line was completed. While the studies on the relationship of music with labor are very limited, they are generally focused on labor pain and anxiety reducing effect of the music. A similar study in this field is the study of Liu et al. in 2010. In this study, it has been concluded that music was effective in reducing pain and anxiety in the early stages of delivery in primipar pregnant women. ${ }^{29}$ However, none of the current studies in the literature examined stress, anxiety and depression during episiotomy with music, besides, it was not examined whether there are differences between the effects of different music genres.

Music can be used by women to hypnotize themselves and provide relief at birth. The chosen music increases the feeling of relaxation, the mother's capacity to meet the baby's needs, and the sense of control. Most of the studies on the use of audioanalgesia at birth have reported that this method increases pain tolerance, support and strength, rhythmically breathing, and movement. ${ }^{30}$ Phumdoung and Good found that continuous sedative music reduced severe pain in labor. ${ }^{31}$ They explained the mechanism of action of music on birth can be explained by the gate control theory of pain. Soft music reduces stress of active labour pain in the first 3 hours. Desiring the baby, expectations about labor pain, and support systems helped women to cope with pain. ${ }^{31}$ Our study differed from the current literature in terms of its results. Although it has been reported that music reduced stress and anxiety in women in labor, in our study there was no significant difference in anxiety and depression levels between pregnant women who listened music and those who did not. Perhaps this was the result of our choise to play music only in active labour and episiotomy.

There are data in the literature regarding that making patients listen to music can be an effective method in relieving labor pain. ${ }^{32,33,34}$ In this respect, our study also differs from the current literature. It has been shown that making pregnant women listen to music also has no significant effect on visual pain scores.

Although the subject difference may be due to many factors, we think that the most important reason is that the patient group in our study did not consist entirely of nullipara patients. The presence of pregnant women with previous labor experience among the patients may have led to a decrease in stress and anxiety. This may have played a role in the absence of a statistically significant improvement as the mean stress and anxiety levels were not too high at the beginning of the delivery.

One of the most important findings of our study is lower stress scores in the patient group who listen to Turkish pop music. Although the stress scores of both listening to music groups were better than the control group, the fact that having the lowest stress score more evident in the group listening to Turkish music can be explained by the thought that the patients will be easier to interact with the music they listen to in their mother language.

When the working group and the non-working group are divided into subgroups in terms of music genre, it is observed that there is a difference in terms of stress in the music subgroups between the working and nonworking groups, while there is no difference in the internal music subgroups of the working and non-working 
groups in terms of stress. In other words, the type of music did not affect stress in both the non-working group and the working group. However, it can be said that the stress is statistically less in the working group than in the non-working group, regardless of the type of music. That is, there is a difference between music groups in terms of stress (in non-stress order (53.3\%, 83.3\%, and 26.7\%; $\mathrm{p}=0.004$ ), but the main source of the difference seems to be related to the patient's working or working position, regardless of music.

Our study also has some methodological limitations. The non-standard parities of the patients included in the study may have led to differences in anxiety and stress levels among patients with different parity. In addition, the total homogeneity of the groups compared in terms of some parameters could not be achieved as desired.

As a result, our study shows significant differences from the current literature in this field with its results. Although making patients listen to music is not very effective in reducing anxiety and depression related to labor, it was observed to have a positive effect on stress. It can be said that this effect is revealed more evidently with the music which has lyrics in the mother language of the pregnant woman. In the future, there is a need for studies which have study plans that have more homogeneous groups in terms of demographic and qualitative characteristics, and in which the effects of different music genres on different stages of delivery were investigated. 


\section{References}

1. Schetter C D, Tanner L. Anxiety, depression and stress in pregnancy: implications for mothers, children, research, and practice Current Opinion in Psychiatry 2012; 25 (2): 141-8

2. Shahhosseini, Z, Pourasghar M, Khalilian A, Salehi F. A Review of the Effects of Anxiety During Pregnancy on Children's Health. Materia Socio Medica 2005; 27(3): 200-2.

3. Kinsella M T, Monk C. Impact of Maternal Stress, Depression and Anxiety on Fetal Neurobehavioral Development. Clinical Obstetrics and Gynecology 2009; 52(3): 425-40.

4. Coussons-Read M E. Effects of prenatal stress on pregnancy and human development: mechanisms and pathways. Obstetric Medicine 2013; 6(2): 52-7.

5. Mulder E J, Robles de Medina P, Huizink A, Van den Bergh B R, Buitelaar J, Visser, G H. Prenatal maternal stress: effects on pregnancy and the (unborn) child. Early Human Development 2002: 70(12): 3-14.

6. Gitau R, Fisk N M, Glover V. Maternal Stress in Pregnancy and its Effect on the Human Foetus: An Overview of Research Findings. Stress 2001; 4(3): 195-203.

7. Sarkar P, Bergman K, O'Connor T G, Glover V. Maternal Antenatal Anxiety and Amniotic Fluid Cortisol and Testosterone: Possible Implications for Foetal Programming. Journal of Neuroendocrinology 2008; 20(4): 489-96.

8. Lin L C, Lee WT, Wang CH. Et al. Mozart K. 448 acts as a potential add-on therapy in children with refractory epilepsy. Epilepsy \& Behavior 2011; 20(3): 490-3.

9. Chirico A, Maiorano P, Indovina P, Milanese C, Giordano GG, Alivernini F. Virtual reality and music therapy as distraction interventions to alleviate anxiety and improve mood states in breast cancer patients during chemotherapy. Journal of Cellular Physiology 2020; 235(6): 5353-62

10. Witusik A, Pietras T Music Therapy as a Complementary Form of Therapy for Mental Disorders Pol Merkur Lekarski 2019; 47(282): 240-3.

11. Loewy J, Goldsmith C, Deshpande S. et al. Music Therapy in Pediatric Asthma Improves Pulmonary Function while Reducing Hospitalizations. J Asthma 2020; 23: 1-9.

12. Ko S Y, Leung, D Y, Wong E M. Effects of easy listening music intervention on satisfaction, anxiety, and pain in patients undergoing colonoscopy: a pilot randomized controlled trial. Clinical Interventions in Aging 2019; 14: 977-86.

13. Liu, Y H, Lee C S, Yu C H, Chen C H. Effects of music listening on stress, anxiety, and sleep quality for sleep-disturbed pregnant women. Women \& Health 2015; 56(3): 296-311.

14. Hepp P, Hagenbeck C, Gilles J. et al. Effects of music intervention during caesarean delivery on anxiety and stress of the mother a controlled, randomised study. BMC Pregnancy and Childbirth 2018;18(1): 435. 
15. Carroli G, Mignini L. Episiotomy for vaginal birth. Cochrane Database of Systematic Reviews. 2009; (1): CD000081. doi: 10.1002/14651858.CD000081.pub2. (edited in 2012)

16. Collins SL, Moore RA, McQuay HJ. The visual analogue pain intensity scale: what is moderate pain in millimetres? Pain 1997;72(1-2):95-7

17. Bilgel N, Bayram N. Psychometric Properties of the Turkish Version of the Depression Anxiety Stress Scale (DASS-42). Arch Neuropsychiatry. 2010; 47: 118-26

18. Walker R E, Choi T S T, Quong S, Hodges R, Truby H, Kumar A. "It's not easy" - A qualitative study of lifestyle change during pregnancy. Women and Birth 2019, PMID: 31587965 doi: 10.1016/j.wombi.2019.09.003

19. Jallo N, Salyer J, Ruiz R J, French E. Perceptions of Guided Imagery for Stress Management in Pregnant African American Women. Archives of Psychiatric Nursing 2015; 29(4): 249-54.

20. Simavli S, Kaygusuz I, Gumus I, Usluogulları B, Yildirim M, Kafali H. Effect of music therapy during vaginal delivery on postpartum pain relief and mental health. Journal of Affective Disorders 2014; 156: 194-9.

21. Ebneshahidi A, Mohseni M. The effect of patientselected music on early postoperative pain, anxiety, and hemodynamic profile in cesarean section surgery. J Altern Complement Med. 2008;14(7):827-31.

22. Chang HC,Yu CH,Chen SY, Chen $\mathrm{CH}$. The effects of music listening on psychosocial stress and maternal-fetal attachment during pregnancy.Complement Ther Med. 2015;23(4):509-15.

23. Chang MY, Chen $\mathrm{CH}$, Huang KF. Effects of music therapy on psychological health of women during pregnancy. J Clin Nurs. 2008;17(19):2580-7

24. Mc Donald, J. S. (2006). Obstetric pain. In: McMahon SB, Koltzenburg M, editors. Wall and Melzack"s Textbook of Pain. 5th ed. Edinburgh: Churchill Livingstone pp.793-816.

25. Alehegan, S., Lundberg, U., Melin, B., Wijma, K. (2011). Catecholamine and Cortisol Reaction to Childbirth. Int J Behav Med, 8(1): 50-65.

26. Alehegan, S., Wijma, B., Lundberg, U., Wijma, K. (2005). Fear, Pain and Stress Hormones During Childbirth. J Psychosom Obstet Gynaecol, 26(3):153-65.

27. Simavli S., Gumus I., Kaygusuz I., Yildirim M., Usluogullari B., Kafali H. (2014). Effect of music on labor pain relief, anxiety level and postpartum analgesic requirement: a randomized controlled clinical trial. Gynecol Obstet Invest. 78(4):244-50. 61.

28. García González J, Ventura Miranda M I, Requena Mullor M, Parron Carreño T, Alarcón Rodriguez R. Effects of prenatal music stimulation on state/trait anxiety in full-term pregnancy and its influence on childbirth: a randomized controlled trial. The Journal of Maternal-Fetal \& Neonatal Medicine 2017; 31(8): 1058-65.

29. Liu, Y H, Chang M Y, Chen C H. Effects of music therapy on labour pain and anxiety in Taiwanese firsttime mothers. Journal of Clinical Nursing 2010; 19(7-8): 1065-72. 
30. Simkin P, Bolding A. Update on nonpharmacologic approaches to relieve labor pain and prevent suffering. J Midwifery Women's Health. 2004;49:489-504.

31. Phumdoung S, Good M. Music reduces sensation and distress of labor pain. Pain Management Nursing 2003;4:54-61.

32. Smith C A, Levett K M, Collins C T, Armour M, Dahlen H G, Suganuma M. Relaxation techniques for pain management in labour. Cochrane Database of Systematic Reviews. 2018.

33. Hosseini S E, Bagheri M, Honarparvaran N. Investigating the Effect of Music on Labor Pain and Progress in the Active Stage of First Labor Eur Rev Med Pharmacol Sci 2013; 17(11): 1479-87.

34. Yu-Hsiang Liu, Mei-Yueh Chang and Chung-Hey Chen. Effects of music therapy on labour pain and anxiety in Taiwanese first-time mothers. J Clin Nurs. 2010 Apr;19(7-8):1065-72. 